\title{
Seven myths of organic agriculture and food research
}

\author{
Bernhard Freyer (D) - Jim Bingen • Valentin Fiala
}

Received: 23 October 2017 / Accepted: 9 April 2018 / Published online: 12 May 2018

(C) The Author(s) 2018

\begin{abstract}
Organic agriculture and food research (OAFR) is well established and there is an ongoing and vibrant discussion about the future research needs of organic farming. However, reviews of the research features of OAFR have been less common. During the editorial work on a collection of book sections about the state of the art of OAFR, we felt that the differences between the ideals of OAFR and the actual research practices invited critical debate. In this article, we label these differences - somewhat provocatively — as myths about OAFR. We identified seven myths: (1) OAFR follows a systemic research approach, (2) OAFR is guided by the International Federation of Organic Agriculture Movements Principles and organic regulations, (3) research priorities are defined in collaboration with practitioners, (4) transdisciplinarity is a key strategy in OAFR, (5) OAFR produces results that are directly applicable in practice, (6) the methods applied in OAFR differ fundamentally from those in research on conventional farming, and (7) organic researchers are fully integrated in the scientific community. We assume that our reflections will also inspire a broader discourse in the light of Organic 3.0, where a critical review of research practices should be central for the future development of OAFR.
\end{abstract}

B. Freyer $(\bowtie) \cdot$ J. Bingen $\cdot$ V. Fiala

Universitat fur Bodenkultur Wien (BOKU), Vienna, Austria

e-mail: bernhard.freyer@boku.ac.at

\section{J. Bingen}

Michigan State University, East Lansing, MI, USA
Keywords Organic agriculture and food research . Research methodology · Organic 3.0

\section{Introduction}

Today, organic agriculture and food research (OAFR) is well established in many agricultural research institutions. Within the context of the future of organic farming (OF), International Federation of Organic Agriculture Movements (IFOAM) prepared a strategic paper, Organic 3.0, that includes an extensive debate about the necessary requirements and important research needs in OF (Arbenz et al. 2015; Niggli et al. 2008, 2016). Besides that, over the last decade, numerous papers have addressed the following: how OF should be developed in the future; research strategies for OF; the demand, needs, and challenges of OF; analyses of the state of the art in OAFR based on stakeholder and expert interviews, focus group discussions, platforms, or literature reviews (Barabanova et al. 2015; Häring et al. 2012, Niggli et al. 2008; Padel et al. 2010; Rahmann et al. 2009), and evaluations of OAFR programs and procedures (Ekert et al. 2012; Lange et al. 2006; Wolf et al. 2011). These activities, focusing largely on the development of OAFR in Europe, have been organized partly through different institutions (see, e.g., DAFA Forum in Germany (DAFA 2015; Hamm et al. 2016)).

When it comes to research features in OAFR, we recognize that the discourse about them is limited and fragmented. The last and maybe sole comprehensive discussion on OAFR methodological features and ideals 
dates back from a review in the 1990s (see Lindenthal et al. 1996). Also work of several mainly Danish researchers represents a significant exception, but focuses first of all on an ethical and systemic research perspective, however serve as an excellent example how the discourse on methodologies can be initiated (Alrøe 2000; Alrøe and Kristensen 2002; Noe and Alrøe 2003; Noe et al. 2008; Thorsøe et al. 2014; Watson et al. 2006). Their research is not only specifically directed on OAFR, but is inspired from experiences with OAFR (Alrøe et al. 2016; Alrøe and Noe 2011, 2014; Noe and Alrøe 2012; Noe et al. 2015). The TIPI report ${ }^{1}$ offers also some insights into research method and approaches, systems perspectives, and participatory aspects of research (Niggli et al. 2016). But when we look at the diverse papers on the future of organic farming, research features are not an issue (e.g., Rahmann et al. 2016). Further observations have been done within the context of the application of systems theory and inter- and transdisciplinarity in organic farming research, where we identified discrepancies between what the science community claims and what is reality in scientific practice (Freyer 2016a, b). Consequently, we argue that OAFR lacks critical discourse on research features (see also Jörgensen 2016).

Based on those observations, we believe that it is important to launch a new discussion about the research characteristics of OAFR. We structure our reflections using the term myth. A myth represents an idealistic image of OAFR that conflicts with the research practices and overall conditions of the science daily routines. Similar to Roland Barthes (1972), we see myths as connotations that present phenomena as natural conditions, when in fact they are socially constructed. The term "myth" has polemic sharpness and we use it in this article pragmatically as a conceptual "lightening rod" that draws our attention to the need to question many of our assumptions in regard of OAFR. In the following, we discuss seven myths about OAFR that are of relevance for the methodological discussions and for the continuing development of organic farming. For each myth, we present how prevalent it is in OAFR, why it is a myth, and further discuss different related consequences and suggest measures for improvement.

\footnotetext{
${ }^{1}$ Technology Innovation Platform of IFOAM-Organics International (TIPI)-A Global Vision and Strategy for Organic Farming Research
}

Why this is necessary? OF is still far from a mainstream food and farming practice. To unpack the potential of organic farming, it is necessary to develop research methodologies and practices that can help to better understand and develop OF's specific qualities, including its potentials and limitations. Therefore, it should be of interest for scientists to critically analyze current state of the art of OAFR features in order to optimize their scientific quality. At least the diffuse nature of OAFR reviews and critical assessments beg for a book-length discussion to provide an overview of the current state of the art and the future of OAFR, which of course we cannot provide here. The idea of this article is therefore to initiate a critical discussion on the OAFR challenges and needs within the context of organic agrofood systems.

\section{Material and methods}

The foundation for the identification and discussion of the seven myths arises from insights gained while preparing an edited volume on OAFR (see Freyer 2016a). In this book (Freyer 2016b), 52 authors contributed 33 chapters and discussed the state of the art, and the future challenges of different fields within OAFR. After reviewing each of the chapters, we identified a list of myths. The list is not complete, nor without flaws, and we invite readers to reflect on our suggestions and to help extend and refine it. In addition, we reviewed additional literature that is related to the myths. We conclude with a brief discussion on how to address these controversies and some ideas for developing the methodological approach and practices of OAFR.

\section{Results and discussion}

Myth 1: OAFR follows a systemic research approach

It is often noted that organic agriculture follows a systemic rather than a more reductionist research approach often found in conventional agriculture. Organic farmers exclude certain external inputs, focus on the farm internal relations (e.g., between crop rotation and pest management or herd size and on-farm forage production), and try to close nutrient and energy cycles, and the farm is understood as an organism (Raupp 2000). Also ideally, organic farming aims for a systemic 
marketing approach with short supply chains and direct consumer-producer relations (Freyer and Bingen 2015; Vogt 2007). Here organic products, their processing, trade, and consume is embedded in the regional economy. Therefore, it is often stated that organic farming is a system-oriented form of agriculture (see e.g., HøghJensen 1998). This assumption is underlined by the IFOAM Principles, which also refer to systemic concepts like wholeness, cycles, and systems.

From this orientation researchers deducted certain requirements for OAFR. For example, Lindenthal et al. (1996) stated that there are five requirements that shall ensure a system-orientated research approach within OAFR: (1) a holistic approach, (2) long-term research, (3) consideration of local characteristics, (4) praxis orientation, and (5) regionality. The implementation of these requirements - which of course can also be discussed critically, but can serve as a guide for the discourse-asks for an inter- and transdisciplinary research design. For that, systems theory has been identified as a necessary theoretical foundation (Fiala and Freyer 2016; Freyer et al. 2010; Gibbon 2002; Ison 2008). The notion that OAFR follows a systemic approach seems to be widespread in the organic research community. Furthermore, "organic farming" is a prominent topic within the International Farming Systems Association (see Barbier et al. 2012), a community dedicated to foster the application of systems theory in the area of agricultural research, and also a central reference in the discourse on farming systems research in general (Darnhofer et al. 2012).

However, no comprehensive research about the application of systems theory in OAFR exists so far and our observation is that researchers commonly discuss the need for a systems perspective on OF, but rarely apply systems theory. The whole area of organic farming systems research has been also criticized to use the word "systemic" often quite freely without applying concrete systems approach (Bawden 1995, 2012; Fiala and Freyer 2016). Also when we look at the five requirements for systems-orientated research (Lindenthal et al. 1996), it becomes clear that not many research projects or publications can fulfill these criteria (Fiala and Freyer 2016) and mostly remain disciplinary orientated (see myth 5 and Freyer 2016a). Häring et al. (2012) state for true systemic research project, runtimes of 25 years would be necessary. There are some examples of long-term field trials (e.g., see overview Mayer and Mäder 2016), but researchers do not spend much time to dig into the details of systems theory and to unfold their potential for a deeper understanding of the organic system. ${ }^{2}$

Missing systems theory in higher education but also time constrains that are given through tight research schedules risk that the organic research community becomes more and more unaware of the need to conduct truly systemic i.e. systems research. The discrepancy between myth and reality is problematic for OFAR and its research community, because it creates blind spots that can be problematic for practitioners. There is need to initiate a broader scientific discourse about this discrepancy; otherwise, we will face problems like it is mentioned in the strategy for organic farming research by the Technology Innovation Platform of IFOAM, where it is stated that system-orientated organic farming research would be necessary, but is very hard to achieve (Niggli et al. 2016).

Myth 2: OAFR is guided by the IFOAM Principles and organic regulations

The understanding of the organic regulations is that they have to be in line with the IFOAM Principles and consequently the organic farming practices are guided by this ethical framework (see Padel et al. 2009; Freyer and Bingen 2015), but it is not so simple as such. Since more than one decade, we observe what is called bifurcation of the organic movement (Constance et al. 2008), representing a broad range of actors with rather different worldviews. As organic regulations continue to be modified, largely by economic (often corporate) interests, they increasingly appear to have almost forgotten the principles (e.g., through the increased application of all

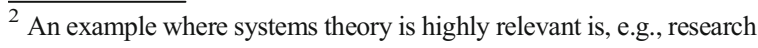
from Noe and Alrøe (2012), referring to Niklas Luhman's social systems theory (Luhmann 1995). They explain the operational closure and systems logic of a farming system and how this closure is produced and reproduced. These insights are also significant for understanding the circumstances under which the conversion of a farm occurs and why the conversion is one of the most challenging steps for an organic actor (Freyer and Bingen 2012, 2014), and in combination with practice theory (Nicolini 2012), the systems' perspective helps us understand this process by highlighting the linkage between practices and social systems. Another example is introduced by Nuutila and Kurppa (2016). They combined a systems perspective with the activity theory to interpret the Finnish organic food chain.
} 
kinds of industrial fertilizers). As a result, organic practices risk losing their singular position as ethically framed (see also the conventionalization debate) (De Wit and Verhoog 2007; Goldberger 2011). The other position is that there are many efforts of farmers, traders, and consumers to seriously reflect their production, trade, and consumer habits following closely the ethical principles.

If and how organic researchers frame their research practices with the IFOAM Principles or not is more or less unknown. In part, the ethical framework of the IFOAM Principles is primarily intended for practice, but not for researchers and how they practice science or how their research aligns with the ethics (Freyer and Bingen 2015). From that perspective, it appears that science and practice live in different worlds and that values are differently of relevance in their daily practice (Freyer and Bingen 2015). Or is this a misinterpretation?

To understand the relation between OAFR and the ethics, a broader view on all kinds of interfaces might be helpful. OAFR reflects the Principles in different ways. There is some research on the development of the Principles (for an overview, see Freyer and Bingen 2015). Principles are part of a broader analysis how they are applied and translated into practices mainly in farming systems (Darnhofer et al. 2010; Padel et al. 2007), but often also within the context of (fair) trade, animal welfare (Vaarst and Alrøe 2012), or their philosophical foundations (Freyer and Bingen 2015). Only in some cases, research is framed by the organic principles (Alrøe and Kristensen 2002). In general, this research field is mainly fed through social scientists, while the majority of natural scientists is less engaged in this topic. If bifurcation also takes place in OAFR is an unknown issue. In this context, it is relevant to inquire about the ethical self-understanding of organic scientists and their awareness of IFOAM Principles in and the consequences for their research (Freyer et al. 2016). While research should not underlie any "moral control," it might be of interest to study how scientists think about ethics and the extent to which the principles influence, i.e., guides the selection of research topic and their research practices.

We can argue that both regulations and IFOAM Principles are based on long-term experiences and are part of a continuous discourse of adaptations. In this sense, they do not limit the option space for research, but guide on already verified findings (Luttikholt 2007; Vogl and Axmann 2016). From this perspective, both principles and regulations do not restrict research, but offer a well-considered framework. $^{3}$ On the other hand, this normative framework might hinder reassessment of the fundamentals of OA and also exclude consideration of possible solutions that could advance organic agriculture and food systems. Further reflections are necessary to clarify the relationship of IFOAM Principles and OAFR, i.e., organic researchers. Similar to many research calls asking today how far the research is in line with or contribute to the sustainable development goals (SDGs), we can argue that for organic research there could be a section asking how far research makes a contribution toward IFOAM Principles.

Myth 3: research priorities are defined in collaboration with practitioners

Historically, farmers and other members of the organic community played an important role to develop and drive OAFR (Vogt 2007). Therefore, there is the widespread opinion that understanding organic farming as system requires the integration of an inter- and transdisciplinary process for the identification of long-term research programs. Research should be done with and for the farmers. Consequently, it seems logical that also the research priorities are defined in collaboration with practitioners and indeed there are some examples for that, e.g., the German Federal Ministry of Nutrition and Agriculture identified priorities by interviewing actors all along the organic agrofood chain (Ekert et al. 2012). IFOAM, initiating the TIPI (Niggli et al. 2016), is working hard on bringing farmers and researchers together to identify research needs. Switzerland established a national forum of farmers and researchers to coordinate research priorities (Nationales

\footnotetext{
${ }^{3}$ With the latest established SDGs (sustainable development goals), OAFR confronts a new and comprehensive ethical framework for sustainable development. SDGs already guide some research programs (e.g., Lund 2015). Consistent with this development, the organic movement should show the extent to which the IFOAM Principles and related programs and activities of the organic movement embody the ethical dimensions of the SDGs (see also Freyer et al. 2016: Niggli et al. 2016; Rahmann et al. 2016). In fact, OAFR itself should begin to critically discuss how the Principles might be adjusted or reinterpreted in light of the SDGs.
} 
Bioforschungsforum: http://www.bioaktuell. ch/aktuell/nbff.html), which is a very promising approach.

How to organize participatory processes is widely discussed in the literature on transdisciplinary research (Enengel et al. 2012, Lang et al. 2012, Leavy 2016, Mobjörk 2010, Scholz and Steiner 2015). However, there are several obstacles in the process of collaboratively defining research strategies. A central challenge in identifying research needs involves finding ways to balance the selection of participating stakeholders with their willingness to be part of such a process. The research topics identified by stakeholder groups might be highly skewed toward the specific interests of those choosing to participate in the process (Baars 2011). Thus, the results may favor those who are most attentive to or interested in the research, while those not participating or interested in the research are excluded. It also makes a difference if stakeholders name research problems purely from their individual perspective, or as a result of a group process or from a broader societal perspective (Fichten 2014). The perspective of stakeholders can fruitfully inform many research topics. But not all research topics are appropriate for or require a stakeholder process. Such research topics might include the development of a method to identify enzymes for a digestion process, or the analysis of the biochemical mechanism of an interaction between a predator and an insect. Also a demand-driven research agenda confronts many tensions, e.g., different and often limited perspectives on innovations of the actors involved; sometimes conflicting processes, monitoring, and output evaluation criteria; and information and knowledge asymmetries between the actor groups (Noe et al. 2015), even there are serious efforts and experiences to reduce these differences (Ingram et al. 2018; Röhrig 2006). These factors might influence researchers' capacity to successfully act in the research planning. Because the majority of those involved often lack the capacity to initiate such a process, "participation" does not per se increase research quality (Klerkx and Leeuwis 2009). But it is the researcher's responsibility to adapt, i.e., transform stakeholder ideas into the research setting, if they claim to practice farmer-oriented research. And without question, a comprehensive literature review should be always part of the research process, even when the focus is stakeholder-driven research.
Myth 4: transdisciplinarity is a key strategy in organic farming research practice

Transdisciplinary research often linked with action research (Hadorn et al. 2006; Reason and Bradbury 2001) - defined as not only crossing disciplinary boundaries (interdisciplinarity) but also including nonacademic stakeholders in the research process (Jahn 2008)- has become quite popular in Farming Systems Research and also in OAFR. In OAFR, calls for research proposals increasingly require scientists to identify how the proposed research will meet the needs of farmers (Freyer 2004, 2016a). Although the collaboration between practitioners and researchers is not an issue that is specific to OAFR, organic farming has a strong history in farmer-driven research (Fiala and Freyer 2016). It seems natural that the lack of institutional support during the pioneer phase of the organic farming movement (Barton 2018; Vogt 2007; Willer and Schmid 2016) led to a high importance of on-farm research in close collaboration with farmers to advance organic farming practices in comparison to mainstream farming (Vogl et al. 2015). Therefore, it is not surprising that in early discussions about the methodological requirements for organic farming, the high importance of and relevance for practitioners was emphasized (Lindenthal et al. 1996).

Today, researchers still face many hindrances, if they want design transdisciplinary research projects. First, conducting transdisciplinary research requires certain competencies (see Muhar et al. 2013; Nash et al. 2003). Without those competencies, researchers will struggle to manage the complex and sometimes exhausting process of integrating stakeholders in their project. Unfortunately, teaching transdisciplinary competencies is still rare in higher education (Dedeurwaerdere 2013; Merck and Beermann 2015; Sherren 2008) and by far not a common part of many OARF-related curricula. The establishment of respective lectures often faces institutional problems, because of the special features of didactic methods (e.g., case study research (see Freyer and Muhar 2006; Larson et al. 2011)) necessary to train transdisciplinary competencies.

Second, although more and more calls demand a transdisciplinary research approach, there are institutional barriers to design projects that way. Often, it is not possible to include stakeholders already in the proposal writing process and there are too little resources to manage the transdisciplinary processes; workload necessary to conduct successful transdisciplinary research 
is underestimated (for example, see the difficulties faced in the "FarmPath" project (Pinto-Correia et al. 2015), or the agricultural European Innovation Partnership (EIP_AGRI), ${ }^{4}$ where farmers are obliged to take over the administration and paperwork, which is going beyond their capacities). ${ }^{5}$ In addition, there are currently still few incentives to conduct transdisciplinary research since most of the scientific journals still focus on disciplinary approaches (Roux et al. 2017). ${ }^{6}$ On the other hand, there are also excellent examples, e.g., the German "Demonstrationsbetriebe," showing how to communicate organic farming practices with the public, ${ }^{7}$ or the "Leitbetriebsnetzwerk" guided by the University of Bonn, which demonstrates how to establish a researcher-farmer collaboration on farm research approach (Berg et al. 2003).

To summarize including stakeholders into the research process is a crucial part for OAFR, but it must not become a hollow buzzword. We have to be clearly aware of the limitations, the difficulties, and the costs connected with moving out of the ivory tower. This awareness should lead to more adaptable research institutions in regard of funding and proposal design and in higher education systems that prepare organic researchers for this demanding task. It is further recommended to link with the diverse research communities engaged in transdisciplinary research since decades.

Myth 5: OAFR produces results that are directly applicable in practice

As already mentioned in myths 3 and 4, the (immediate) usefulness of results for practitioners is often identified as a key feature of OAFR, already raised in the early days of organic farming (e.g., Lindenthal et al. 1996). Indeed, basic research within the field of OAFR is rare, and OAFR has a long tradition of focusing on applied research approaches. This dominance of applied research may also be due to the demand for solutions that can be directly transferred into practice (Ekert et al. 2012). Farmer's interest is the usefulness of a research result under real farming conditions, while for

\footnotetext{
$\overline{{ }^{4} \text { https://ec.europa.eu/eip/agriculture/en/european-innovation- }}$ partnership-agricultural

${ }^{5}$ Statement by BioAustria representatives

${ }^{6}$ Of course there are excellent exceptions, e.g., the GAIA Journal (http://www.ingentaconnect.com/content/oekom/gaia).

${ }^{7}$ https://www.oekolandbau.de/verbraucher/demonstrationsbetriebe/
}

researchers, interests are beyond this target, including also simply to test, evaluate, or monitor something,

Thus, it is a misconception that results from applied science automatically guarantee their (short term) applicability in practice. The transferability of research results is confronted with four challenges: (1) Organization - the direct application of research results often requires additional resources that are not considered to be part of classical research projects. (2) Qualificationscientists are only partly qualified for this task, because transforming and transferring results into practice is its own profession (Fichten 2014). (3) Appropriatenessnot all research results qualify for direct application. The research intents other objectives or refers to other methodological approaches relevant for the research process that offers no space for a transfer oriented strategy. (4) Time-research projects that are limited to 3 years often cannot produce scientifically robust and qualified results to recommend farmers. ${ }^{8}$

Transdisciplinary action research (Stokols 2006) includes the practice orientation but often risk failing due to the mentioned challenges under myth 4 (see also Dressel et al. 2014; Freyer 2004; Freyer and Muhar 2006; Hoffmann et al. 2009; Rieckmann 2015; Ison 2008). In addition, those action-orientated approaches come with another trade-off: If the focus is more on a specific farming system, a kind of case study approach, the produced results may show great ways to improve the situation within this farming system, but may not be applicable in any other farm. This can be explained not only through site-specific agro-ecological conditions but also because of the farmers influenced in these trials, i.e., the management capacities or the technical equipment of a farm. In such case study-oriented research, which has its own value (Flyvbjerg 2006), the aim is not the direct applicability of a result in other farms, but to find the best solutions from a systems perspective for one farm.

To summarize OAFR aims at producing research results that are directly applicable in practice. To be realistic, from a research point of view, this target is not always to fulfill, due to the intended research focus, i.e., the research objectives and other factors. Furthermore, it requires specific competencies, institutional support, and additional resources. In general, we still face obstacles how to measure the scientific and non-scientific impacts of transdisciplinary research (Wolf et al. 2013),

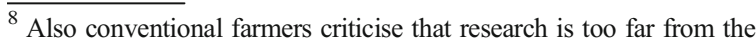
practical needs and demands (Isermeyer 2003)
} 
which provides the procedures and (mixed) methods (Popa et al. 2015) to guarantee high applicability of research results in practice (Green 2008).

Myth 6: the methods applied in OAFR differ fundamentally from those in research on conventional farming

Since it is often stated that OAFR has specific requirements and that it follows a systemic approach, as well as ethical principles, it is sometimes assumed that OAFR methods also differ from methods applied in conventional farming research. But no meta-studies are available to confirm this assumption. During the editorial work of the book Ökologischer Landbau-Grundlagen, Wissensstand und Herausforderungen (Freyer 2016b), we concluded that with the exception of plant and animal breeding, ethics, and research on bio-dynamic agriculture (Geier et al. 2016; Herold 2016; Horneburg 2016), currently alternative methodological approaches that are specifically developed and applied in OAFR are limited. ${ }^{9}$ We only can observe that some methods are more relevant in OAFR research, e.g., microbiological soil analysis (Mäder et al. 2002), than others, or specific methods are excluded, which is the case, e.g., in animal and plant breeding.

When it comes to the results of any applied method, we observe differences between both farming approaches. Same results must not lead to the same interpretations and consequences in practice. For example, both conventional and organic researchers concerned the availability of phosphorous in the soils, but they propose quite different management solutions. In organic farming, the crop rotation and organic manure and compost management as well as the $\mathrm{pH}$ are to optimize, and the nutrient status (farm gate and plot specific) is to analyze before adding any fertilizer from outside the farm. In conventional farming, the first recommendation almost always is to apply mineral fertilizer. In each system, also the recommended type and amounts of fertilizers are different.

More research sector specific detailed analyses and the identification of differences and communalities in the application of methods between organic and conventional

\footnotetext{
${ }^{9}$ An example for methods that are specifically in organic farming research is the spade diagnosis (Munkholm 2000), which originally was not developed by organic actors (Görbing 1947), or bio-dynamic research, which includes so called "holistic" methods, e.g., chromatographic methods for assessing the quality of products (Turinek et al. 2009; Weibel et al. 1998).
}

research, and more in-depth reflections about the need of new or alternative methods to understand and further develop the organic system in future, would be useful. Also, it seems natural that both researcher groups can learn from each other, how they apply methods and interpret results (Rahmann et al. 2016).

Myth 7: organic researchers are fully integrated into the wider scientific community

Given the broad range of OAFR, it appears that organic farming has become a topic of interest within the wider scientific community. Publications and scientific conferences on organic farming have been increasing in the last two decades (see www.orgprints.org/). There are numerous options to present OAFR in scientific peerreviewed journals, as well as conferences, including those journals that traditionally were established for research on conventional agricultural. From that perspective, we can conclude that organic research and the related research community are well embedded in the overall scientific community.

When we look at the "organic" researchers, we identify different types with different access to the organic and the conventional research society: (a) researchers who focus only on OAFR, (b) those who deal with both conventional and organic systems, (c) those who do OAFR by default, and (d) those who exclude OAFR, but write critically about it. These researchers are differently integrated and linked in the organic researcher networks (e.g., ISOFAR, TIPI, etc.) as well as in the diverse conventional ones. Hülsbergen and Rahmann (2014) argue that the circle of organic researchers has grown very slowly in recent years, as documented as well by Ekert et al. (2012). DAFA (2015) similarly notes that the contribution of basic science researchers in OAFR is very limited. These observations indicate that there is an untapped research potential between the different research groups - organic and non-organic - that could benefit from greater communication. This potential addresses not only new topics, i.e., technologies and methods in the natural sciences, or, e.g., developments in transdisciplinary sciences (Brandt et al. 2013), but also contributions from scientific disciplines that have been less engaged in OAFR, e.g., medicine, or methodologies that have not paid attention to organic farming practices and product qualities. It is also clear that the organic research community is a relatively small one and has a limited number of research facilities and institutes with often low 
financial capacities, including laboratories, or budgets to employ a broad range of methods. In short, it may be of interest for organic researchers to intensify the collaboration with non-organic researchers/institutes, and who, in turn, may become inspired to engage into OAFR and related research topics.

\section{Conclusions}

There has been little debate over organic farming, organic agriculture, and food research since Lindenthal et al. (1996). This article summarizes and critically discusses the current situation along seven myths about OAFR. We expect that what we reflect as a myth may generate some controversy and disagreements; however, it was intended with this article to initiate a critical discourse. Some of our initial conclusions include:

- There is need to specify in the diverse organic research sectors the systems approach, activating the tool box of all kinds of systems theories and methods.

- IFOAM Principles guide the organic practices and therefore should be more part of research on organic farming and their future development.

- Best practices on identification of research priorities in collaboration with stakeholders should be further strengthened; however, it is to keep in mind that there are cases where researchers have to follow other research priorities.

- Organic researchers should access the transdisciplinary scientific movement and their theoretical and methodological discourses to better use the potential of transdisciplinary tools and related mixed methods.

- There is need for a more detailed discourse on the applicability and transferability of research results. Not each research is qualified due to its problem structure, and related methods for developing solutions. This is also to communicate to the stakeholders.

- A research platform on organic farming methodologies and (systems) theories, e.g., supported via a European COST action or the establishment of a platform like FQS (www.qualitative-research.net/), might offer a format to deepen the debate on (innovative) OAFS-specific methods and their potential to innovate the organic farming system.
- Recommendations are of low significance if not supported by the research policies and budgets in the respected countries as well as activities specifically in higher education to train students in the field of organic agriculture and food sciences.

Especially in the context of the further development of organic farming as "Organic 3.0/4.0," we argue the importance for the scientific community to engage with these myths, to reflect upon them, and to discover others. We have done so, and we invite others to do so as well. We believe that such reflection could launch an important creative process for increasing the research quality for the organic agriculture and food system.

Acknowledgements We thank the anonymous reviewers for their critical and helpful feedback.

Funding Information Open access funding provided by University of Natural Resources and Life Sciences Vienna (BOKU).

Open Access This article is distributed under the terms of the Creative Commons Attribution 4.0 International License (http:// creativecommons.org/licenses/by/4.0/), which permits unrestricted use, distribution, and reproduction in any medium, provided you give appropriate credit to the original author(s) and the source, provide a link to the Creative Commons license, and indicate if changes were made.

\section{References}

Alrøe HF (2000) Science as systems learning: some reflections on the cognitive and communicational aspects of science. Cybern Hum Know 7(4):57-78

Alrøe HF, Kristensen ES (2002) Towards a systemic research methodology in agriculture: rethinking the role of values in science. Agric Hum Values 19(1):3-23

Alrøe HF, Moller H, Læssøe J, Noe E (2016) Opportunities and challenges for multicriteria assessment of food system sustainability. Ecol Soc 21(1)

Alrøe HF, Noe E (2011) A cross-disciplinary approach to multicriteria assessment and communication of the effects of organic food systems. Org Life-Knowl Tomorrow 2: 313-316

Alrøe HF, Noe E (2014) A prototype tool for multicriteria assessments to develop organic food chains. Build Org Bridg 1: 195-198

Arbenz M, Gould D, Stopes C (2015) Organic 3.0 or truly sustainable farming and consumption. IFOAM - Organics International, Bonn https://shop.ifoam.bio/en/organic-30truly-sustainable-farming-consumption

Baars T (2011) Experiential science; towards an integration of implicit and reflected practitioner-expert knowledge in the scientific development of organic farming. J Agric Environ Ethics 24(6):601-628 
Barabanova U, Zanoli R, Schlüter M, Stopes C (2015) Transforming Food \& Farming. In: An organic vision for Europe in 2030. IFOAM EU Group, Brussels

Barbier M, Bompart M, Garandel-Batifol V, Mogoutov A (2012) Textual analysis and scientometric mapping of the dynamic knowledge in and around the IFSA community. In: Darnhofer I, Gibbon D, Dedieu B (eds) Farming systems research into the 21st century: the new dynamic. Springer, Dordrecht, Heidelberg, New York, London, pp 73-95

Barthes R (1972) Mythologies. Hill and Wang, New York

Barton GA (2018) The global history of organic farming. Oxford University Press, Oxford

Bawden R (1995) On the systems dimension inFSR. J Farm Syst: Res Ext 5(2):1-18

Bawden R (2012) How should we farm? The ethical dimension of farming systems. In: Darnhofer I, Gibbon D, Dedieu B (eds) Farming systems research into the 21st century: the new dynamic. Springer, Dordrecht, pp 119-140

Berg M, Haas G, Leisen E, Schenke, H (2003) Stickstoffmanagement im ökologisch wirtschaftenden Betrieb: Minderung von Stickstoffverlusten.[Hrsg.] Landwirtschaftliche Fakultät der Rheinischen Friedrich-Wilhelms-Universität Bonn. Dokumentation 10 Jahre Leitbetriebe ökologischer Landbau in Nordrhein-Westfalen. Schriftenreihe des Lehr-und Forschungsschwerpunktes: Umweltverträgliche und Standortgerechte Landwirtschaft 105:64-75

Brandt P, Ernst A, Gralla F, Luederitz C, Lang DJ, Newig J et al (2013) A review of transdisciplinary research in sustainability science. Ecol Econ 92:1-15

Constance DH, Choi JY, Lyke-Ho-Gland H (2008) Conventionalization, bifurcation, and quality of life: certified and non-certified organic farmers in Texas. South Rural Sociol 23(1):208-234

DAFA (2015) (Hrsg.) Fachforum Ökologische Lebensmittelwirtschaft - Forschungsstrategieentwurf der Deutschen Agrarforschungsallianz, Braunschweig, Version 27.11.2015

Darnhofer I, Gibbon D, Dedieu B (2012) Farming systems research: an approach to inquiry. In: Darnhofer I, Gibbon D, Dedieu B (eds) Farming systems research into the 21st century: the new dynamic. Springer, Dordrecht, pp 3-31

Darnhofer I, Lindenthal T, Bartel-Kratochvil R, Zollitsch W (2010) Conventionalisation of organic farming practices: from structural criteria towards an assessment based on organic principles. Rev Agron Sustain Dev 30(1):67-81

Dedeurwaerdere T (2013) Transdisciplinary sustainability science at higher education institutions: science policy tools for incremental institutional change. Sustainability 5(9):37833801

De Wit J, Verhoog H (2007) Organic values and the conventionalization of organic agriculture. NJAS-Wagening J life Sci 54(4):449-462

Dressel G, Berger W, Heimerl K, Winiwarter, V. (Eds.). (2014) Interdisziplinär und transdisziplinär forschen: Praktiken und Methoden. Transcript Verlag, Bielefeld

Ekert S, Döring T, Häring AM, Lampkin N, Murphy-Bokern D, Otto K et al (2012) Evaluation des Bereichs Forschung und Entwicklung im Bundesprogramm Ökologischer Landbau. Forschungsgemeinschaft Organic Research Evaluations, Berlin
Enengel B, Muhar A, Penker M, Freyer B, Drlik S, Ritter F (2012) Co-production of knowledge in transdisciplinary doctoral theses on landscape development — an analysis of actor roles and knowledge types in different research phases. Landsc Urban Plan 105(1):106-117

Fiala V, Freyer B (2016) Systemtheoretische Grundlagen. In: Freyer B (ed) Ökologischer Landbau: Grundlagen, Wissensstand und Herausforderungen. UTB, Stuttgart, pp 80-101

Fichten W (2014) Spurensuche: Hat Praxisforschung systemische Wirkungen? TriOS. 9. Jahrgang, Heft 1/2014, 55

Flyvbjerg B (2006) Five misunderstandings about case-study research. Qual Inq 12(2):219-245

Freyer B (2004) Inter- und transdisziplinäre ForschungspraxisBeobachtungen und Empfehlungen. Institut für Ökologischen Landbau, Universität für Bodenkultur, Wien

Freyer, B. 2016a. Konturen der Forschung im Ökologischen Landbau, 652-693. In B. Freyer (Ed.), Ökologischer Landbau. Grundlagen, Wissensstand und Herausforderungen (pp. 652-694). Stuttgart: UTB

Freyer, B. 2016b. (Eds.). Ökologischer Landbau: Grundlagen, Wissensstand und Herausforderungen. Stuttgart: UTB

Freyer B, Bingen J (2012) The transformation to organic: insights from practice theory: INTECH Open Access Publisher

Freyer B, Bingen J (2014) Organic and non-organic farming: is convergence possible? In D. ., M-C. Renard, \& M. RiveraFerre (Eds.) Alternative Agrifood Movements: Patterns of Convergence and Divergence (pp. 281-310): Emerald Group Publishing Limited

Freyer B, Bingen J (2015) Re-thinking organic food and farming in a changing world. Springer, Dordrecht, Heidelberg, New York, London

Freyer, B., Bingen, J., \& Helgenberger, S. 2010. How transdisciplinarity becomes a member in the club of science-some preliminary thoughts on the contribution of systems theory to theorizing transdisciplinarity: na

Freyer B, Klimek M, Fiala V (2016) Ethik im Ökologischen Landbau-Grundlagen und Diskurse. In: Freyer B (ed) Ökologischer Landbau: Grundlagen, Wissensstand und Herausforderungen. UTB, Stuttgart, pp 44-79

Freyer B and Muhar A. 2006. Transdisziplinäre Kooperation in der universitären Ausbildung: die Fallstudie" Leben 2014" in der Nationalparkregion Hohe Tauern, Oberpinzgau; ein Projekt im Rahmen des Programms Kulturlandschaftsforschung, Wien: facultas Verlag

Geier U, Fritz J, Greiner R, Olbrich-Majer M (2016) Biologischdynamische Landwirtschaft. In: Freyer B (ed) Ökologischer Landbau: Grundlagen, Wissensstand und Herausforderungen. UTB, Stuttgart, pp 101-123

Gibbon D (2002) Systems thinking, interdisciplinarity and farmer participation: essential ingredients in working for more sustainable organic farming systems. Paper presented at the Proceedings of the UK Organic Research 2002 Conference, Organic Centre Wales, Institute of Rural Studies, University of Wales Aberystwyth

Goldberger JR (2011) Conventionalization, civic engagement, and the sustainability of organic agriculture. J Rural Stud 27(3): 288-296

Görbing J (1947) Die Spatendiagnose: Ziel und Grundlage biologisch zweckmässiger Bodenbearbeitung. Verlag Sachse, Hamburg 
Green LW (2008) Making research relevant: if it is an evidencebased practice, where's the practice-based evidence? Fam Pract 25:20-24

Hamm U, Häring A, Horn S, Hülsbergen $\mathrm{H}$, Isermeyer F, Lange S, ... Rahmann G (2016) (Ed.) Future strategy of the organic food and farming sector. A result of a particpatory approach with the stakeholders 2014-2016. Prepared for the Fachforum Ökologische Lebensmitttelwirtschaft of the German Agricultural Research Alliance (pp. 19). Braunschweig, Germany

Hadorn GH, Bradley D, Pohl C, Rist S, Wiesmann U (2006) Implications of transdisciplinarity for sustainability research. Ecol Econ 60(1):119-128

Häring AM, Blodau S, Braun C, Meyerhof C, Winkler C (2012) Forschung zur ökologischen Land-und LebensmittelwirtschaftAnsatzpunkte für eine Interessensvertretung. Schriften zu den Wirtschafts-und Sozialwissenschaften der Land-und Lebensmittelwirtschaft

Herold P (2016) Tierzüchtung. In: Freyer B (ed) Ökologischer Landbau: Grundlagen, Wissensstand und Herausforderungen. UTB, Stuttgart, pp 567-587

Hoffmann V, Thomas A, Gerber A (eds) (2009) Transdisziplinäre Umweltforschung; Methodenhandbuch. Oekom Verlag, München

Høgh-Jensen H (1998) Systems theory as a scientific approach towards organic farming. Biological agriculture \& horticulture 16(1):37-52

Horneburg B (2016) Ökologische Pflanzenzüchtung, 406-420. In: Freyer B (ed) Ökologischer Landbau: Grundlagen, Wissensstand und Herausforderungen. UTB, Stuttgart

Hülsbergen, K.-J., \& Rahmann, G. 2014. Die Zukunft des Systems Ökolandbau - Zusammenfassende Auswertung einer Umfrage vom Mai 2014. In DAFA (Ed.), http://www.dafa. de/fileadmin/dam_uploads/images/Fachforen/FF Oekolandbau/befragungsauswertung-ffoe-2014.pdf

Ingram J, Dwyer J, Gaskell P, Mills J, de Wolf P (2018) Reconceptualising translation in agricultural innovation: a co-translation approach to bring research knowledge and practice closer together. Land Use Policy 70:38-51

Isermeyer F (2003) Für eine leistungsfähige Agrarforschung in Deutschland. In Agrarstruktur und Ländliche Räume Inst. für Betriebswirtschaft, Braunschweig \& Arbeitsbericht 05/2003 Bundesforschungsanstalt für Landwirtschaft (FAL), Schriftliche Fassung eines Vortrags, der mit anderem Titel auf dem 115. VDLUFA-Kongress in Saarbrücken am 16.09.2003

Ison R (2008) Systems thinking and practice for action research. In: Peter W, Bradbury H (eds) The Sage Handbook of Action Research Participative Inquiry and Practice. Sage Publications, London, pp 139-158

Jahn T (2008) Transdisciplinarity in the practice of research (Translation from "Transdisziplinarität in der Forschungspraxis."). In M. Bergmann \& E. Schramm (Eds.), Transdisziplinäre Forschung: integrative Forschungsprozesse verstehen und bewerten. (pp. 21-37). Frankfurt am Main: Campus Verlag

Jörgensen RG (2016) Bodenfruchtbarkeit. In: Freyer B (ed) Ökologischer Landbau: Grundlagen, Wissensstand und Herausforderungen. UTB, Stuttgart, pp 298-316

Klerkx L, Leeuwis C (2009) Operationalizing demand-driven agricultural research: institutional influences in a public and private system of research planning in the Netherlands. J Agric Educ Ext 15(2):161-175

Lang DJ, Wiek A, Bergmann M, Stauffacher M, Martens P, Moll P et al (2012) Transdisciplinary research in sustainability science: practice, principles, and challenges. Sustain Sci 7(1): $25-43$

Lange, S., Williges, U., Saxena, S., \& Willer, H. 2006. Research in organic food and farming. Reports on organization and conduction of research programs in, 11 European Countries. Bonn, Germany: Bundesanstalt für Landwirtschaft und Ernährung (BLE)/Federal Agency for Agriculture and Food

Larson EL, Landers TF, Begg MD (2011) Building interdisciplinary research models: a didactic course to prepare interdisciplinary scholars and faculty. Clin Transl Sci 4(1):38-41

Leavy P (2016) Essentials of transdisciplinary research: using problem-centered methodologies. Routledge, New York

Lindenthal, T., Vogl, C.R., \& Heß, J. 1996. Forschung im Oekologischen Landbau: integrale Schwerpunktthemen und Methodikkriterien Der Foerderungsdienst (Austria). no. 2c. Sonderausgabe

Luhmann N (1995) Social systems: Palo Alto: Stanford University Press

Lund C (2015) Poverty, inequality and mental health in low-and middle-income countries: time to expand the research and policy agendas. Epidemiol Psychiatric Sci 24(2):97

Luttikholt LW (2007) Principles of organic agriculture as formulated by the International Federation of Organic Agriculture Movements. NJAS-Wagening J Life Sci 54(4):347-360

Mäder P, Fliessbach A, Dubois D, Gunst L, Fried P, Niggli U (2002) Soil fertility and biodiversity in organic farming. Science 296(5573):1694-1697

Mayer J, Mäder P (2016) Langzeitversuche-Eine Analyse der Ertragsentwicklung. In: Freyer B (ed) Ökologischer Landbau: Grundlagen, Wissensstand und Herausforderungen. UTB, Stuttgart, pp 421-443

Merck J, Beermann M (2015) The relevance of transdisciplinary teaching and learning for the successful integration of sustainability issues into higher education development Integrative Approaches to Sustainable Development at University Level (pp. 19-25). Heidelberg: Springer

Mobjörk M (2010) Consulting versus participatory transdisciplinarity: a refined classification of transdisciplinary research. Futures 42(8):866-873

Muhar A, Visser J, Van Breda J (2013) Experiences from establishing structured inter-and transdisciplinary doctoral programs in sustainability: a comparison of two cases in South Africa and Austria. J Clean Prod 61:122-129

Munkholm LJ (2000) The spade analysis - a modification of the qualitative spade diagnosis for scientific use. DIAS, Tieje

Nicolini, D. 2012. Practice theory, work, and organization: an introduction Oxford university press

Nash JM, Collins BN, Loughlin SE, Solbrig M, Harvey R, Krishnan-Sarin S et al (2003) Training the transdisciplinary scientist: a general framework applied to tobacco use behavior. Nicotine Tob Res 5(1):41-53

Niggli U, Slabe A, Schmid O, Halberg N, Schlüter M (2008) Vision for an organic food and farming research agenda to 2025. IFOAM Regional Group European Union, Brussels

Niggli U, Willer H, Baker B (2016) A global vision and strategy for organic farming research, a global vision and strategy for organic farming research. TIPI - technology innovation 
platform of IFOAM - organics international, c/o research Institute of Organic Agriculture (FiBL), Frick, Switzerland

Noe E, Alrøe HF (2003) Farm enterprises as self-organizing systems: a new transdisciplinary framework for studying farm enterprises? Int J Sociol Agric Food 11(1):3-14

Noe E, Alrøe HF (2012) Observing farming systems: insights from social systems theory. In I. Darnhofer, D. Gibbon \& B. Dedieu (Eds.), Farming Systems Research into the 21st century: The new dynamic (pp. 387-403): Springer

Noe E, Alrøe HF, Langvad AMS (2008) A polyocular framework for research on multifunctional farming and rural development. Sociol Rural 48(1):1-15

Noe E, Alrøe HF, Thorsøe MH, Olesen JE, Sørensen P, Melander B, Fog E (2015) Knowledge asymmetries between research and practice: a social systems approach to implementation barriers in organic arable farming. Sociol Rural 55(4):460482

Nuutila J, Kurppa S (2016) The Finnish organic food chain - an activity theory approach. Org Agric 6(1):49-56

Padel S, Niggli U, Pearce B, Schlüter M, Schmid O, Cuoco E et al (2010) Implementation action plan for organic food and farming research. Technology Platform, IFOAM, Bonn

Padel S, Röcklinsberg H, Verhoog H, Fjelsted Alrøe H, de Wit J, Kjeldsen C, Schmid O (2007) Balancing and integrating basic values in the development of organic regulations and standards: proposal for a procedure using case studies of conflicting areas, Report from the Organic Revision project, http://www.organic-revision.org

Padel S, Röcklinsberg H, Schmid O (2009) The implementation of organic principles and values in the European Regulation for organic food. Food Policy 34(3):245-251

Pinto-Correia T, McKee A, Guimaraes H (2015) Transdisciplinarity in deriving sustainability pathways for agriculture. In: I. Darnhofer, L. Sutherland \& L. Zagata (Eds.), Transition Pathways towards Sustainability in Agriculture. (pp. 1-15). Wallingford

Popa F, Guillermin M, Dedeurwaerdere T (2015) A pragmatist approach to transdisciplinarity in sustainability research: from complex systems theory to reflexive science. Futures 65:45-56

Rahmann G, Ardakani MR, Bàrberi P, Boehm H, Canali S, Chander M et al (2016) Organic Agriculture 3.0 is innovation with research. Org Agric 7(3):169-197

Rahmann G, Oppermann R, Paulsen H, Weibmann F (2009) Good, but not good enough? Research and development needs in organic farming. Agric Forest Res 59:29-40

Raupp J (2000) The well-proportioned farm organism. Just a pleasing image of a mixed farming system or rather a basic requirement for functioning organic husbandry? Paper presented at the Proc. 13th Int. IFOAM Sci. Conf., August 2000 Basel

Reason P, Bradbury H (2001) Handbook of action research: participative inquiry and practice. Sage, London

Rieckmann M (2015) Transdisziplinäre Forschung und Lehre als Brücke zwischen Zivilgesellschaft und Hochschulen. ZEP: Zeitschrift für Internationale Bildungsforschung und Entwicklungspädagogik 38(3):4
Röhrig P (2006) Koordination von Maßnahmen zum Wissenstransfer zwischen Forschung und Ökologischer Lebensmittelwirtschaft unter besonderer Berücksichtigung der Ergebnisse des Bundesprogramms Ökologischer Landbau. In E. Saggau (Eds.), Forschung im Bundesprogramm Ökologischer Landbau - Projekte im Forschungsbereich Ökonomie,(pp. 13). Bonn: Bundesanstalt für Landwirtschaft und Ernährung

Roux DJ, Nel JL, Cundill G, O'Farrell P, Fabricius C (2017) Transdisciplinary research for systemic change: who to learn with, what to learn about and how to learn. Sustain Sci 12(5): 711-726

Scholz RW, Steiner G (2015) The real type and ideal type of transdisciplinary processes: part II-what constraints and obstacles do we meet in practice? Sustain Sci 10(4):653-671

Sherren K (2008) A history of the future of higher education for sustainable development. Environ Educ Res 14(3):238-256

Stokols D (2006) Toward a science of transdisciplinary action research. Am J Community Psychol 38(1-2):79-93

Thorsøe M, Alrøe H, Noe E (2014) Observing the observers: uncovering the role of values in research assessments of organic food systems. Ecol Soc 19(2)

Turinek M, Grobelnik-Mlakar S, Bavec M, Bavec F (2009) Biodynamic agriculture research progress and priorities. Renew Agric Food Syst 24(02):146-154

Vaarst M, Alrøe HF (2012) Concepts of animal health and welfare in organic livestock systems. J Agric Environ Ethics 25(3): $333-347$

Vogt G (2007) The origins of organic farming. In: Lockeretz W (ed) Organic farming: an international histor. CABI, Wallingford, pp 9-29

Vogl CR, Axmann P (2016) Regelungsmechanismen. In: Freyer B (ed) Ökologischer Landbau: Grundlagen, Wissensstand und Herausforderungen. UTB, Stuttgart, pp 124-145

Vogl CR, Kummer S, Leitgeb F, Schunko C, Aigner M (2015) Keeping the actors in the organic system learning: the role of organic farmers' experiments. Sustain Agric Res 4(3):141148

Watson C, Alrøe H, Kristensen ES (2006) Research to support development of organic food and farming. CSIRO Publishing, Clayton

Weibel F, Bickel R, Leuthold S, Alföldi T (1998) Are organically grown apples tastier and healthier? A comparative field study using conventional and alternative methods to measure fruit quality. Paper presented at the XXV International Horticultural Congress. Brussels: ISHS

Willer H, Schmid O (2016) Geschichte. In: Freyer B (ed) Ökologischer Landbau: Grundlagen, Wissensstand und Herausforderungen. UTB, Stuttgart, pp 22-43

Wolf B, Lindenthal T, Szerencsits M, Boland H, Heß J (2011) Evaluierung praxisorientierter Ökolandbauforschung. Paper presented at the Wissenschaftstagung Ökologischer Landbau. Es geht ums Ganze: Forschen im Dialog von Wissenschaft und Praxis, Giessen, 15.-18. März 2011

Wolf B, Lindenthal T, Szerencsits M, Holbrook JB, Heß J (2013) Evaluating research beyond scientific impact how to include criteria for productive interactions and impact on practice and society. GAIA-Ecol Perspect Sci Soc 22(2):104-114 